Sudarenko Olena,

$\mathrm{PhD}$ (Law Sciences), Associate Professor, Kyiv National University of Trade and Economics, 19, Kyoto str., Kyiv, 02156, Ukraine ORSID: 0000-0002-4336-546X,

Researcher ID: C-2858-2019

Senchenko Ljudmyla,

$\mathrm{PhD}$ (Law Sciences), Associate Professor, Kyiv National University of Trade and Economics, 19, Kyoto str., Kyiv, 02156, Ukraine ORSID: 0000-0002-4397-4898

Researcher ID: O-2653-2016

\title{
STATE IS A REQUIRED SUBJECT OF FINANCIAL LEGAL AFFAIRS
}

A systematic structural analysis of the participation of the state as a subject of financial law and a subject of financial relations is carried out. The legal relationships in which the state acts as the subject of financial legal relations are determined.

Key words: subject of law, subject of legal relation, state as the subject of financial law, state as the subject of financial legal relations.

Сударенко Олена, Сенченко Людмила. Держава - неодмінний суб'єкт рінансових відносин.

Проводиться систематичний структурний аналіз участі держави як суб'єкта фінансового права та суб'єкта фінансових відносин. Визначаються правовідносини, в яких держава виступає суб'єктом фінансових правовідносин.

Ключові слова: суб'єкт права, суб'єкт правовідносин, держава як суб'єкт фінансового права, держава як суб'єкт фінансових правовідносин.

Relevance of the research. The state is an indispensable subject of law. Representatives of the scientific community of each national branch of law make appropriate statements in their scientific work. New theories are emerging, such as the theory of human-centrism, the theory of legal anthropology, etc., which provide new approaches to the study of relevant issues. At the same time, in recent years, there have been scientific works that state that the subject of law is a party to certain legal relationships, but does not belong to the subjects of legal relations in which it is participates $(12$, p. 13, 211-212). Codes contain articles that identify the participants in the relationship, including in the field of business, participants in the budget 
process, etc. (L.K. Voronova, N.P. Kucheryavenko, 2003; 6). However, the state is not specified as a party of these legal relationships in the codes.

Formulation of the problem. The purpose of the research is to investigate the issue of state involvement in financial relationships as a subject of financial law and a subject of financial relations, to determine relationships in which the state acts as a subject of financial relations directly, and in which through authorized bodies.

Analysis of recent research and publications. Questions about the relationship between the concepts of «subject of law» and «subject of legal relations» were the subject of study not only representatives of science of theory of state and law, but also financial and other branches of law. Important in scientific terms for the authors were works: Aljeksjejev S.S., Voronova L.K., Dmytryk O.O., Isajeva N.K., Komarov S.O., Kucherjavenko M.P., Pryshva N.Ju., Rovinsjkyj Ju.A., Khalfina R.O., Khaustova M.Gh. and others. At the same time, questions about the relation between the concepts of «subject of law» and «subject of legal relations» do not remain relevant today. So, Manukh O.V. in her doctoral thesis determined that the state is a subject of law, is a party to certain legal relation, but does not belong to subject of legal relationship. Also in scientific papers it is noted that the state is a direct subject of legal relations only in international financial relations (if we talk about financial law). All this leads to the need to study the issue of state participation in financial relations as a subject of law and a subject of financial relations.

Presenting of main material. In the concept of «subject of law», scientists distinguish two main characteristics: the potential for participation in legal relationships; real participation in them (S.S. Alekseev, 1981, p. 140; N.P. Kucheryavenko, 2004, p. 313; M.Gh. Khaustova, 2009; R.O. Khalfina, 1974, p. 114). «Subject of law (legal personality)» is a broader concept, somewhat different from the concept of «subject of legal relations» (R.O. Khalfina, 1974, p. 115-116). The subject of law is transformed into a participant of legal relations, which is subject of legal relations (M.Gh. Khaustova, 2009, p. 34). The authors of the textbook «Financial Law» state that the concept of «subject of financial law» should be regarded as primary and general, and the concept of «subject of financial relations» as secondary and specific. Subjects of financial law are legal and natural persons endowed with financial personality, through which they are potentially capable of participating in financial relations. Subjects of financial legal relations are real, actual participants (legal and natural persons) of specific financial legal relations, which are holders of subjective rights and legal obligations. (N.Ju. Pryshva, 2018, p. 57).

Therefore, the subject of legal relations is a real participant of legal relations. Also classic is the composition of the legal relationship: the object, the subject (not the participant) and the content of the legal relationship. The science of financial law has determined the peculiarities of financial legal relationships: their emergence, change and termination occurs in the sphere of financial activity of the state and local selfgovernment bodies; this activity is related to the planned mobilization, distribution and 
use of centralized and decentralized public funds; their occurrence, change and termination are related to a financial act - they are based on the law or decision of the respective local authority; lack of equality between parties to financial relationships; one of the indispensable subjects of financial legal relations is the state or local selfgovernment body or their authorized bodies (O.A. Dmitrik, 2004, p. 16-34; Ye.A. Rovinskiy, 1960, p. 134-138; I.V. Rukavishnikova, 2006, p. 168-169; O.V. Sudarenko, 2010, p. 213). The subjects of financial legal relations are: 1) the state (in relations with other states or international organizations); 2) territorial community; 3) public authorities; 4) local self-government bodies; 5) National Bank of Ukraine; 6) business entities; 7) budgetary institutions and other non-profit organizations; 8) nationals (including foreign nationals and stateless persons) (19, p. 57-58). The state acts, as a rule, and represented by it: the Verkhovna Rada, the President, the Cabinet of Ministers, the Ministry of Finance, the National Bank (and in international financial relations the state acts as the subject of relations) (L.K. Voronova, 2003, p. 76-77). The state issues power orders, obliging subjects to execute them, so a party to a legal relationship opposite to the state is always given, above all, a duty for the legitimate, effective exercise of which it is granted certain rights. (S.S. Alekseev, 1995, p. 226, 231; N.Ju. Pryshva, 2004, p. 24-25; I.V. Rukavishnikova, 2006, p. 8, 58-64, 97-100, 162, 165-169, 174).

Given the scientifically developed peculiarities of financial legal relationships, it is of scientific interest to identify those legal relationships in which the state acts as the subject of the legal relationship directly, and in which through its authorized bodies. Public authority is embodied (organized, «materialized») in the apparatus of power (state apparatus). The most important feature of the state is sovereignty, which means independence and autonomy in defined and implemented policies both inside and outside the state (S.A. Komarov, 1998, p. 27). The supremacy of the state lies first and foremost in the legal subordination to it of all subjects within the state territory. The decision of the basic questions of the organization of society belongs exclusively to the state itself. The legal definition of competence of public authorities is not a restriction of power, but a way of exercising sovereignty (Ju.S. Shemshuchenko, 1998, p. 684-685).

In our opinion, the state is a direct subject of financial relations not only in international financial relations. So, when founding of each state, there is necessarily a question about the shape of the territorial system: unitary state or federal. The form of the territorial structure of the state is inevitably linked to the budgetary system and structure of the state's tax system. So, for unitary states it is a two-tier budgetary system and the presence of state and local taxes, for federal states - a three-tier budgetary system, and the presence of state, federal and local taxes. A wellconstructed tax system allows to identify all the positive features through the state's tax policy. Each state is endowed with sovereignty and is entitled to a national currency. Of course, the issue of the currency is carried out by the main bank of the 
state in Ukraine - the National Bank of Ukraine. However, the hryvnia is the national currency of Ukraine, not the National Bank. When we talking about the national currency, we always associate it with the state - the currency of Ukraine, the currency of China and so on. Are the issues related to the issue of the monetary unit of the country related to international legal relations (foreign sovereignty)? No. The only legal payment unit on the territory of Ukraine is the ghryvnja. Ensuring the stability of the currency of Ukraine is the main constitutional obligation of the National Bank, not the state.

Therefore, the direct subject of financial legal relations in the sphere of establishment of the budgetary system, establishment of taxes and the tax system, in the sphere of currency issue is the state itself. The state exercises these rights during its creation. At the same time, changes in the state's tax system occur throughout its existence, and the system of state (namely state, not parliamentary, as parliament passes laws) changes taxes and fees. If the state exercised its «one-off» rights, can it be said that it does not belong to the subjects of financial legal relations? In our opinion, no.

The sovereign financial powers of the state include: the right to adopt financial laws, set taxes, conclude contracts on government borrowing, apply compulsory measures to violators or executors of financial norms (N.Ju. Pryshva, 2018, p. 58). One of the parties to a financial relationship is the entity that has the power to issue authority (state or its authorized body) (O.O. Gholovashevych, 2018, p. 16). The state as a direct participant of the tax relationship takes part in the relations that arise in the process of establishing, introducing taxes and fees, as well as changing and abolishing them. The state itself is the owner of the funds paid in the form of taxes that come to the revenue part of the state budget, moreover the state is the subject of responsibility in case of illegal tax collection (N.P. Kucheryavenko, 2004, p. 315). On the one hand, the state empowers the competent authorities with powers and controls the flow of funds into the budgets. On the other hand, tax revenue is one of the main channels of formation of state ownership, although initially in a specific monetary form (10, p. 14). In case the taxpayer fails to perform or improperly perform the constitutional duty to pay the taxes, the state will use all its means and techniques to enforce that obligation. The funds that we pay in the form of taxes are directed by the state and local selfgovernment bodies to fulfill their tasks and functions and to satisfy the public interest. Thus, in the tax as well as in the financial legal relations, the organizational role of the state and local self-government is manifested, so they are power and property in nature. (L.K.Voronova, 2003, p. 35; L.K.Voronova, 2006, p. 34-35, 216; O.O Gholovashevych, 2018, p. 14; N.Ju. Pryshva, 2004, p. 75)

The state and administrative-territorial entities act in budgetary relations, because they are given the right for budget by the Constitution of Ukraine, and hence their right to receive income and finance the expenses related to the exercise of functions entrusted to them by the Constitution. These subjects are also involved in government credit related legal relationships as they are granted the right to issue 
government local loans (L.K. Voronova, 2003, p. 76-77). The Constitution of Ukraine has granted the right to its own budget as a material financial basis for the functioning of the state and local self-government bodies of all levels. An important provision of the Constitution of Ukraine is the statement that the state participates in the formation of revenues of local government budgets, financially supports it. This item is in line with the World Declaration of Local Self-Government and the European Charter of Local Self-Government, which provide for strong guarantees of financial and material autonomy of local self-government bodies in the exercise of their budgetary powers. (L.K. Voronova, 2003, p. 131; N.K. Isajeva, 2001, p. 274) There is also no question that the state is the owner of the state budget. The powers of Ukraine as a sovereign state in the area of the budget are wide. Voronova L.K. in accordance with the norms of the articles of the Constitution of Ukraine and the Budget Code of Ukraine, divides them into two groups of powers: which belong to Ukraine as a state on the territory of which a single fiscal policy is developed and implemented; which are connected with the fact that the State budget plays the main role in the budgetary system of Ukraine (L.K. Voronova, 2003, p. 134-137).

The state as a whole is the subject of law in state-legal and some property relations (in particular, the realization of property rights, circulation of bonds, etc.) (Ju.S. Shemshuchenko, 1998, p. 680). The role and place of the state in financial activity is characterized by a certain duality: on the one hand, the state acts as an economic entity, which combines the status of the owner of funds and the organizer of economic activity, on the other - the state acts as the bearer of the authorities, which is realized in the sphere of financial activities (L.K. Voronova, 2003, p. 13). However, recent scientific publications state that the state is a party to legal relations only when it comes to international relations. The state does not participate in financial relations within the state. «For example, the responsibility for the public debt is borne by Ukraine as a state subject to financial law.» (L.K. Voronova, 2003, p. 33; N.Ju. Pryshva, 2018, p. 57). Therefore, the state owns tort. And then the question arises: Can a subject that is not a subject of legal relations to be tortuous? Since legal obligations are decisive in characterizing financial personality, only a person who is able to take responsibility for their actions in the field of financial activity is capable of realizing them. (L.K. Voronova, 2003, p. 57).

If one holds that the state is the subject of financial relations only in the sphere of international financial law, then in the relations of state borrowings and state guarantees there is a «double situation»: in the international legal relations on the state debt the subject of responsibility is the state, and in the relations of the state the internal debt is not the state, but the body that issued the bonds (we do not focus now on the fact that it is financed from the state budget). Is this possible? With regard to international legal relations, the answer here is one - the subject of these legal relationships is the state, but it is also represented by government bodies. In addition, part 2 p. 1 art. 16 of the Budget Code, states that the right to carry out government 
borrowing belongs to the state in the person of... the Minister of Finance of Ukraine, on behalf of the Cabinet of Ministers of Ukraine. In this case, government borrowing is carried out within the limits set by the law on the state budget of Ukraine. Therefore, the legal structure (set of legal facts) is required, the definition of the right by the parliament in the law on the state budget for the respective year, the adoption of a specific decision by the government, and the direct actions of the Minister of Finance. In these legal relationships, the decision of the Minister of Finance or the government alone is not sufficient, in this case there must be a decision of both the representative body and the executive authority - «the totality of decisions of the bodies of more than one branch of government» involved in the said legal relations. The situation is similar with regard to the provision of the foreign exchange reserve of Ukraine, which is under the supervision of the National Bank of Ukraine and the Government. Court fees and proceeds from the pledge to the state income are the source of formation of the special fund of the State Budget (L.K. Voronova, 2003).

New types of financial relationships include government lending, only in 2010, they acquired the legitimate name of «budgeting». Budgeting - refunding, payment and maturity transactions that cause budget commitments (budgetary credits) and budgeting operations (budgetary repayments) (3). A prime example of government lending is government housing lending programs. And here again the question arises who exactly lends the following: State, Parliament, Government or State Fund for Youth Housing Assistance? The logical answer is the state. However, if you follow the latest scientific developments - then the State Fund for Youth Housing Assistance. And where did this Fund get funds to lend? From the state budget (the vast majority). In these legal relations, again, «the totality of decisions of bodies of more than one branch of government» (representative bodies and executive authorities) is required therefore the subject of legal relations is the state. This conclusion is confirmed by the fact that the individual has an obligation to pay interest and the principal amount for the use of credit funds to the State (State Budget), and not to the State Youth Housing Assistance Fund. The same situation will be the case when it comes to state aid to economic entities at the expense of state and local resources. (13)

Conclusion. The state is an indispensable subject of financial legal relations, which acts in them directly or through its authorized bodies. The state is a direct subject of financial relations not only in international financial relations. There are rights that the state exercises in its creation - the rights associated with sovereignty (the right to budget and budget system; the right to taxes and the tax system; the right to the currency of the state; the right to issue financial laws). The state is also a direct subject of financial legal relations if the legal structure of such legal relations is characterized by «the totality of decisions of bodies of more than one branch of government.» In particular, we are talking about the relationship between government borrowing and government guarantees (internal and external), government lending (budgeting), and public financing of relevant sectors of the economy. 


\section{REFERENCES}

1. Alekseev, S.S. (1981). Obshchaya teoriya prava (General Theory of Law). In 2 Vol. (Vols. 2), Moscow: Yurid. lit. (in Russian).

2. Alekseev, S.S. (1995). Teoriya prava (Theory of Law). Moscow: BYeK (in Russian).

3. Bjudzhetnyj kodeks Ukrajiny № 2456-VI vid 08.07.2010 (Budget Code of Ukraine). Gholos Ukrajiny - Voice of Ukraine, № 143 (in Ukrainian).

4. Voronova, L.K. \& Kucheryavenko, N.P. Finansovoe pravo: Uchebnoe posobie dlya studentov yuridicheskikh vuzov i fakultetov (Financial Law: manual for students of law schools and faculties). Kharkov: Legas, 2003. 360 p. (in Russian).

5. Voronova, L.K. Finansove pravo Ukrajiny: Pidruchnyk (Financial Law of Ukraine: Textbook). Kyiv: Precedent; Moja knygha, 2006. 448 p. (in Ukrainian).

6. Ghospodarsjkyj kodeks Ukrajiny № 436-IV vid 16.01.2003 (Economic Code of Ukraine). Oficijnyj visnyk Ukrajiny - Official Bulletin of Ukraine, № 11, Article 462 (in Ukrainian).

7. Dmitrik, O.A. (2004). Soderzhanie i klassifikatsiya finansovykh pravootnosheniy: Monografiya (The content and classification of financial legal relations: Monograph). N.P. Kucheryavenko (Ed.). Kharkov: Legas (in Russian).

8. Isajeva, N.K. (2001). Materialjno-finansovi (ekonomichni) osnovy miscevogho samovrjaduvannja. Municypaljne pravo Ukrajiny: Pidruchnyk (Material and financial (economic) bases of local self-government. Municipal Law of Ukraine: Textbook). V.F. Poghorilko, O.F Frycjkyj (Eds.). Kyjiv: Jurinkom Inter (in Ukrainian).

9. Komarov, S.A. (1998). Obshchaya teoriya gosudarstva i prava: Uchebnik (General Theory of State and Law: Textbook). Moscow: Yurrayt (in Russian).

10. Gholovashevych, O.O. \& Kotenko, A.M. et al. (2018). Podatkove pravo Ukrajiny: pidruchnyk (Tax law of Ukraine: textbook). Kharkiv: Pravo (in Ukrainian).

11. Kucheryavenko, N.P. (2004). Kurs nalogovogo prava (Tax Law Course). In 6 Vol. (Vols. 2), Kharkov: Legas (in Russian).

12. Manukh, O.V. (2017). Dynamika finansovykh pravovidnosyn: metodologhichnyj aspect (Dynamics of financial relationships: methodological aspect). Doctor's thesis. Zaporizhzhja. Retrieved from http://phd.znu.edu.ua/page/dis/07/ Makukh_diss.pdf (in Ukrainian).

13. Zakon Ukrajiny «Pro derzhavnu dopomoghu sub'jektam ghospodarjuvannja» № 1555-VII vid 01.07.2014 (Law of Ukraine «On State Aid to Entities»). Gholos Ukrajiny - Voice of Ukraine, № 146 (in Ukrainian).

14. Pryshva, N.Ju. (2010). Podatkove pravo: navch. posib. (Tax Law: teach manual). Kyjiv: Jurinkom Inter (in Ukrainian). 
15. Pryshva, N.Ju. (2004). Pravovi problemy reghuljuvannja obov'jazkovykh platezhiv (Legal Issues Regulating Mandatory Payments). Extended abstract of doctor's thesis. Kyjiv: Kyjivsjkyj nacionaljnyj universytet imeni Tarasa Shevchenka (in Ukrainian).

16. Rovinskiy, Ye.A. (1960). Osnovnye voprosy teorii sovetskogo finansovogo prava (The main issues of the theory of Soviet financial law). Moscow: Gosyurizdat (in Russian).

17. Rukavishnikova, I.V. (2006). Metod finansovogo prava (Financial law method). Moscow: Yurist (in Russian).

18. Sudarenko, O.V. (2010). Pravo na zhytlo: derzhavne finansuvannja budivnyctva. Monoghrafija (The right to housing: state funding for construction. Monograph). Kyiv: Kyjiv. nac. torgh.-ekon. un-t (in Ukrainian).

19. Pryshva, N.Ju. (Eds.). (2018). Finansove pravo: navch. posib. (Financial Law: teach manual). Kyjiv: Vydavnyctvo Lira-K (in Ukrainian).

20. Khaustova, M.Gh. (2009). Sub'jekt prava jak element pravovoji systemy suspiljstva (The subject of law as an element of the legal system of society). Zaghaljni problemy pravovoji nauky - General problems of legal science, № 3, 29-38. Retrieved from nlu.edu.ua/bistream/123456789/5600/1/Haustova_29.pdf (in Ukrainian).

21. Khalfina, R.O. (1974). Obshchee uchenie o pravootnoshenii (General doctrine of legal relationship). Moscow: Yurid. lit. (in Russian).

22. Shemshuchenko, Ju.S. (Eds.). (1998). Jurydychna encyklopedija (Legal Encyclopedia). In 6 Vol. (Vols. 5), Kyiv: Ukr. Encykl. (in Ukrainian). 